\title{
Pembuatan Adsorben Dari Kitosan Cangkang Belangkas (Tachypleus gigas) Dan Gelatin Untuk Menurunkan Kadar Logam Timbal (Pb)
}

\section{Preparation Adsorbent Chitosan of Shell Horseshoe Crab (Tachypleus gigas) and Gelatine to Reduce Pb Content}

\author{
Pada Mulia Raja ${ }^{1 *}$ dan Nurfajriani2 ${ }^{*}$ \\ 1Sekolah Tinggi Ilmu Pertanian Agrobisnis Perkebunan, Kampus LPP Medan, Medan-Indonesia \\ 2Departemen Kimia, Fakultas MIPA, Universitas Negeri Medan, Medan-Indonesia \\ *Korespondensi: padamuliaraja@gmail.com; agam.alazne@yahoo.com
}

\begin{abstract}
Abstrak: Penelitian ini bertujuan untuk mengetahui pembuatan adsorben kitosan dari cangkang belangkas (Tachypleus gigas) dan gelatin dalam menurunkan kadar logam Timbal (Pb). Penelitian ini terdiri dari beberapa tahap yaitu Pembuatan adsorben kitosan dan dari cangkang belangkas (Tachypleusgigas) dan gelatin dan karakterisasi logam Timbal $(\mathrm{Pb})$ setelah adsorben diaplikasikan. Perlakuan larutan kitosan dan larutan gelatin dengan perbandingan $\mathrm{K}_{25}$ : G75, K50 : G50 dan K75 : G25, kemudian pada perlakukan kedua larutan kitosan $2 \%$ ditambah serbuk gelatin dengan variasi $0,1 \mathrm{~g}, 0,2 \mathrm{~g}, 0,3 \mathrm{~g}, 0,4 \mathrm{~g}$ dan $0,5 \mathrm{~g}$. Hasil penelitian diperoleh penurunan kadar logam $\mathrm{Pb}$ yang optimum terdapat pada adsorben campuran kitosan dan gelatin $75 \%: 25 \%$ yaitu $83,696 \%$ dan pada adsorben campuran kitosan $2 \%$ dengan penambahan serbuk gelatin $0,5 \mathrm{~g}$ yaitu sebesar $69,316 \%$.
\end{abstract}

Kata kunci: adsorben, gelatin, kitosan, $\mathrm{Pb}$

\begin{abstract}
The Porpuse of this research are to determine the preparation of chitosan from crab shell (Tachypleus gigas) and gelatine adsorbent to reduce of $\mathrm{Pb}$. This research consists of several stages: Preparation of chitosan adsorbent and crab shell (Tachypleusgigas) and gelatine and characterization of Pb after adsorbent applied. Treatment of chitosan solution and gelatin solution with a ratio K25: G75, K50: G5O and K75: G25, then the second treatment $2 \%$ chitosan solution add gelatin powder with a variation of $0.1 \mathrm{~g}, 0.2 \mathrm{~g}, 0.3 \mathrm{~g}, 0,4 \mathrm{~g}$ and $0.5 \mathrm{~g}$. the results obtained by reduction of $P b$ optimum levels found in adsorbent of chitosan and gelatin mixture of 75\%: $25 \%$ is $83.696 \%$ and $2 \%$ chitosan adsorbent mixture with the addition of $0.5 \mathrm{~g}$ gelatin powder that is equal to $69.316 \%$.
\end{abstract}

Keywords: adsorben, chitosan, gelatin, $\mathrm{Pb}$

\section{PENDAHULUAN}

Pencemaran lingkungan perairan yang disebabkan oleh logam-logam berat seperti kadmium, timbal dan tembaga yang berasal dari limbah industri udah lama diketahui. Untuk menghilang kanbahan pencemar perairan tersebut hingga kini masih terus dikembangkan. Sebagaimana yang kita ketahui limbah dari hewan crustaceaese pertiudang, kepiting dan belangkas di Indonesia hanya dimanfaatkan untuk pakan ternak, hidrolisat protein, silase, bahan baku terasi, petis dan lain-lain, sementara itu, limbah seperti ini di negara-negara maju seperti Jepang dan Amerika Serikat telah diisolasi kitinnya. Kitin juga dapat diubah menjadi kitosan setelah lebih dari 70\% gugus asetilnya dihilangkan. Noviary (2010) Telah melakukan karakterisasi cangkang belangkas, dalam penelitiannya mengemukakan bahwa cangkang belangkas mempunyai kandungan kitin sebesar 86,2 \% dan mempunyai viskositas tinggi yaitu 800-2000 serta mempunyai berat molekul $10^{6}$.

Pemanfaatan kitosan sebagai bahan penjerap (adsorben) dalam berbagai bidang telah banyak dilakukan oleh peneliti-peneliti sebelumya, misalnya dibidang lingkungan perairan tentang adsorpsi kandungan logam $\mathrm{Cr}$ (III) dan Fe (II) yang dilakukan oleh Endang et al. (2008). Adsorpsi logam Cr (III) dan Ni (II) pada limbah cair pelapisan logam dilakukan oleh Meriatna (2008). Adsorpsi logam $\mathrm{Pb}$ (II), Cd (II) dan (Cu) dilakukan oleh Marganof (2003).

Penggunaan kitosan sebagai adsorben masih terbatas karena kelarutannya dalam $\mathrm{pH}$ asam, kemampuan kitosan untuk mengadsorpsi sudah cukup baik, namun selektivitas dan aplikasi kitosan dapat ditingkatkan lagi dengan cara memodifikasinya secara fisika ataupun kimia. Modifikasi kitosan tersebut banyak dilakukan melalui perpaduan kitosan dengan polimer lain, baik 
polimer alam maupun polimer sintetik (Syahriza, 2009). Beberapa penelitian juga memperlihatkan bahwa modifikasi terhadap kitosan dapat meningkatkan daya adsorpsi terhadap logam berat, sebagai contoh penelitian yang dilakukan oleh Amit et al. (2006) penggabungan kitosan dengan gelatine dan ragi kemudian modifikasi kitosan yang terimpregnasi alumina (Endang et al., 2008). Dari beberapa hasil penelitian memperlihatkan bahwa kitosan mampu mengadsorpsi 39 $\mathrm{mg} \mathrm{Cu} / \mathrm{g}$ kitosan; 47,5 mg Ni/ g kitosan; 83 mg Zn/g kitosan, 106,8 mg Cr/g kitosan dan 78,9 mg Pb/g kitosan (Endang et al., 2006), $815 \mathrm{mg} \mathrm{Hg}(\mathrm{II}) / \mathrm{g}$ kitosan (Amit et al., 2006).

Meskipun demikian kemampuan adsorpsi kitosan terhadap logam atau ion logam masih perlu ditingkatkan misalnya dengan memperluas permukaan kitosan atau memperbanyak gugus aktif misalnya memodifikasi dengan senyawa lain.

Gelatin mempunyai sifat hidrofilitas yang tinggi ini dapat dilihat dari fungsinya, dalam produk pangan gelatin berfungsi sebagai penstabil, pembentuk gel, pengikat, pengental, pengemulsi, pelapis dan lain sebagainya.

Lebih jauh Gomes (2011) mengatakan berdasarkan sifat gelatin dan kitosan, perlu dilakukan suatu penelitian yang lebih intensif dalam membahas sifat fisik dan kimia dari kombinasi kedua senyawa tersebut. Kombinasi kedua biopolimer ini akan saling memperbaiki kelemahan serta meningkatkan sifat fisiko-kimia dari gelatin murni maupun kitosan murni.

\section{METODE}

\section{Bahan dan alat}

Bahan utama yang digunakan dalam penelitian ini adalah kitosan dari cangkang belangkas dan gelatin komersil. Sedangkan bahan analisis danpembantu yang digunakan dalam penelitian ini adalah: Tepung ikan, air deionisasi, Larutan Standart Pb (Merck), $\mathrm{NaOH}{ }_{1} \%$ (Teknis), $\mathrm{V}_{2} \mathrm{O}_{5}$ (Merck) $\mathrm{CH}_{3} \mathrm{COOH}$ glasial, p.a (Merck), $\mathrm{HNO}_{3}$ p.a (Merck) dan $\mathrm{HCl}$ p.a (Merck), sedangkan peralatan yang digunakan adalah peralatan gelas kimia (Phyrex) Oven (Memmert) Microwave (Digestion CEM) dan Spektrofotometer Serapan Atom (AAS) (Shimadzu).

\section{Pembuatan larutan gelatin $2 \%$}

Sebanyak 2 g gelatin dilarutkan kedalam $100 \mathrm{~mL}$ air deionisasi. Kelarutan gelatin dalam air sangat dipengaruhi oleh suhu lingkungan, biasanya gelatin akan larut sempurna didalam air pada suhu $60^{\circ} \mathrm{C}$ selama 3 jam. Sebaiknya larutan yang terbentuk segera digunakan, apabila larutan yang terbentuk tidak segera digunakan, disimpan dalam kulkas dan dipanas lebih dahulu jika akan digunakan.

\section{Pembuatan larutan kitosan $2 \%$}

Sebanyak 2 g kitosan dilarutkan kedalam $100 \mathrm{~mL}$ larutan asam asetat $1 \%$. Sebaiknya larutan yang terbentuk segera digunakan.

\section{Penyediaan adsorben kitosan gelatin dengan perbandingan volume \\ Larutan kitosan dan gelatin yang tersedia} di tuangkan ke petridish dengan perbandingan volume kitosan dan gelatin yaitu 25\% : $75 \%, 50 \%$ : $50 \%$ dan $75 \%: 25 \%$, Kemudian dikeringkan di dalam oven pada suhu $60{ }^{\circ} \mathrm{C}$ selama 18 jam, Film kitosangelatin yang terbentuk dilepaskan dari petridish, kemudian dicelupkan kedalam larutan $\mathrm{NaOH} 1 \%$ dan dilanjutkan dengan pencucian berulang-ulang dengan air deionisasi untuk menghilangkan kadar $\mathrm{NaOH}$ dan dikeringkan pada suhu kamar, ulangi prosedur 1 sampai 3 untuk perbandingan kitosan-gelatin 50\% : $50 \%$ dan 75\% : 25\%.

\section{Penyediaan adsorben kitosan-gelatin dengan memvariasikan kadar serbuk gelatin}

Sebanyak $10 \mathrm{~mL}$ larutan kitosan dituangkan ke petridish, kemudian ditaburi dengan serbuk gelatin dengan kadar $0.1 \mathrm{~g}, 0.2$ g, $0.3 \mathrm{~g}, \quad 0.4 \mathrm{~g}$, dan $0.5 \mathrm{~g}$, Kemudian dikeringkan di dalam oven pada suhu $60{ }^{\circ} \mathrm{C}$ selama 18 jam, Film kitosan-gelatin yang terbentuk dilepaskan dari petri dish, kemudian dicelupkanke dalam larutan $\mathrm{NaOH}$ $1 \%$ dan dilanjutkan dengan pencucian berulang-ulang dengan air deionisasi dan dikeringkan pada suhu kamar, ulangi prosedur 1 sampai 3 untuk kadar kitosan 0.2 g-0.5 g, kemudian adsorben diaplikasikan untuk menurunkan kadar logam Timbal (Pb) pada air, selanjutnya air dianalisa yang digunakan dengan menggunakan AAS.

\section{HASIL DAN PEMBAHASAN}

Kemampuan adsorben untuk mengadsorbsi logam timbal $(\mathrm{Pb})$ ditunjukkan pada Tabel 1. Data hasil penurunan logam $\mathrm{Pb}$ setelah dilewatkan pada adsorben kitosangelatin ditunjukkan pada Tabel 2 . 
Tabel 1. Hasil Pengukuran Sampel dengan AAS

\begin{tabular}{ccccccc}
\hline No & Kode & Abs & $\begin{array}{c}\text { Konst } \\
(\mu \mathrm{g} / \mathrm{l})\end{array}$ & $\begin{array}{c}\text { Konst } \\
(\mu \mathrm{g} / \mathrm{g})\end{array}$ & $\begin{array}{c}\text { Nilai } \\
\text { Sertifikat }\end{array}$ & $\begin{array}{c}\text { \% yang } \\
\text { terserap }\end{array}$ \\
\hline 1 & F1 & 0,0094 & 1,919 & $0,191 \pm 0,0572$ & & 51,671 \\
2 & F2 & 0,0146 & 3,311 & $0,330 \pm 0,0078$ & & 16,430 \\
3 & F3 & 0,0078 & 1,478 & $0,147 \pm 0,0296$ & & 62,835 \\
4 & F4 & 0,0059 & 0,971 & $0,096 \pm 0,0055$ & & 75,671 \\
5 & F5 & 0,0047 & 0,654 & $0,064 \pm 0,0046$ & $0,395 \pm 0,050$ & 83,696 \\
6 & F6 & 0,0088 & 1,751 & $0,174 \pm 0,0058$ & & 55,924 \\
7 & F7 & 0,0082 & 1,6 & $0,159 \pm 0,0177$ & & 59,747 \\
8 & F8 & 0,0079 & 1,511 & $0,150 \pm 0,0097$ & & 62,000 \\
9 & F9 & 0,0073 & 1,356 & $0,135 \pm 0,0226$ & & 65,924 \\
10 & F10 & 0,0068 & 1,222 & $0,121 \pm 0,0166$ & & 69,316 \\
\hline
\end{tabular}

Keterangan: $\mathrm{F} 1=$ Kitosan, F2 $=$ Gelatin, F3 $=$ Kitosan $:$ Gelatin $(25: 75), F_{4}=$ Kitosan $:$ Gelatin $(50: 50$ ), F5 = Kitosan : Gelatin $(75: 25)$, F6 = Kitosan + 0,1 g Gelatin, F7 = Kitosan + 0,2 g Gelatin, F8 = Kitosan + 0,3 $\mathrm{g}$ Gelatin, F9 $=$ Kitosan $+0,4 \mathrm{~g}$ Gelatin, F10 $=$ Kitosan $+0,5 \mathrm{~g}$ Gelatin

$\underline{\text { Tabel } 2 \text { Hasil penurunan logam } \mathrm{Pb} \text { setelah dilewatkan dengan adsorben kitosan - gelatin (v/v) }}$

\begin{tabular}{ccccccc}
\hline No & Kode & $\begin{array}{c}\text { Larutan } \\
\text { kitosan } \\
(\mathrm{mL})\end{array}$ & $\begin{array}{c}\text { Larutan } \\
\text { gelatin }(\mathrm{mL})\end{array}$ & $\begin{array}{c}\text { Konst } \\
(\mu \mathrm{g} / \mathrm{l})\end{array}$ & $\begin{array}{c}\text { Konst } \\
(\mu \mathrm{g} / \mathrm{g})\end{array}$ & $\begin{array}{c}\text { \% yang } \\
\text { terserap }\end{array}$ \\
\hline 1 & F1 & 10 & - & 1,919 & $0,191 \pm 0,0572$ & 51,671 \\
2 & F2 & - & 10 & 3,311 & $0,330 \pm 0,0078$ & 16,430 \\
3 & F3 & 2,5 & 7,5 & 1,478 & $0,147 \pm 0,0296$ & 62,835 \\
4 & F4 & 5 & 5 & 0,971 & $0,096 \pm 0,0055$ & 75,671 \\
5 & F5 & 7,5 & 2,5 & 0,654 & $0,064 \pm 0,0046$ & 83,696 \\
\hline
\end{tabular}

Keterangan : F1 = Kitosan, F2 = Gelatin, F3 = Kitosan : Gelatin $(25: 75)$, F4 = Kitosan $:$ Gelatin (50 : 50), F5 = Kitosan: Gelatin $(75: 25)$.

Berdasarkan data Tabel 2 menunjukkan berada pada F2 (larutan gelatin $10 \mathrm{~mL}$ ) yaitu bahwa penurunan kadar logamPb yang optimum beradapada F5 (larutan kitosan 75 \%: larutan gelatin $25 \%$ ) yaitu 82,354 \%, Sedangkan penurunan yang paling rendah $10,812 \%$. Gambar 1 menunjukkan grafik hasil penurunan logam $\mathrm{Pb}$ setelah dilewatkan dengan adsorben kitosan-gelatin (v/v).

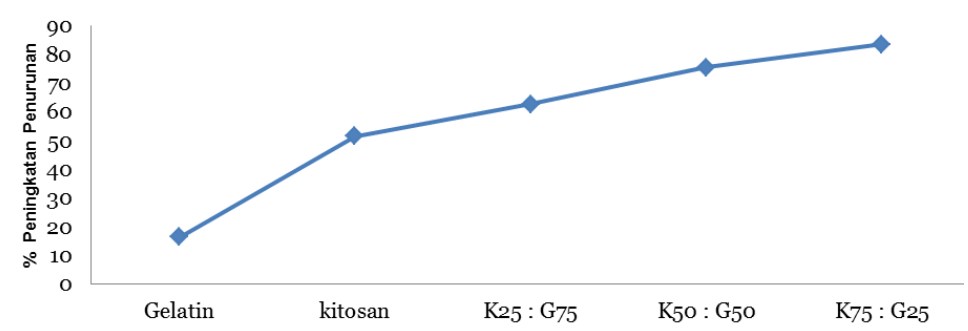

Gambar 1. Grafik hasil penurunan kadar logam $\mathrm{Pb}$ setelah dilewatkan dengan adsorben.

Tabel 3. Hasil penurunan kadar logam Pb setelah dilewatkan dengan adsorben kitosan - gelatin (w/v)

\begin{tabular}{ccccccc}
\hline No & Kode & $\begin{array}{c}\text { Larutan } \\
\text { kitosan } \\
(\mathrm{mL})\end{array}$ & $\begin{array}{c}\text { Gelatin } \\
(\mathrm{g})\end{array}$ & $\begin{array}{c}\text { Konst } \\
(\mu \mathrm{g} / \mathrm{l})\end{array}$ & $\begin{array}{c}\text { Konst } \\
(\mu \mathrm{g} / \mathrm{g})\end{array}$ & $\begin{array}{c}\text { \% yang } \\
\text { terserap }\end{array}$ \\
\hline 1 & F6 & 10 & 0,1 & 1,751 & $0,174 \pm 0,0058$ & 55,924 \\
2 & F7 & 10 & 0,2 & 1,6 & $0,159 \pm 0,0177$ & 59,747 \\
3 & F8 & 10 & 0,3 & 1,511 & $0,150 \pm 0,0097$ & 62,000 \\
4 & F9 & 10 & 0,4 & 1,356 & $0,135 \pm 0,0226$ & 65,924 \\
5 & F10 & 10 & 0,5 & 1,222 & $0,121 \pm 0,0166$ & 69,316 \\
\hline
\end{tabular}

Keterangan :F6 = Kitosan + 0,1 g Gelatin, $\mathrm{F} 7=$ Kitosan + 0,2 g Gelatin, F8 $=$ Kitosan + 0,3 g Gelatin, F9 = Kitosan + $0,4 \mathrm{~g}$ Gelatin, $\mathrm{F} 1 \mathrm{O}=$ Kitosan $+0,5 \mathrm{~g}$ Gelatin. 
Dari Tabel 3 diatas pada F6 (volume kitosan $10 \mathrm{~mL}$ dan serbuk gelatin $0,1 \mathrm{~g}$ ) persen penurunan kadar logam $\mathrm{Pb}$ sebesar 55,924 \% dan pada F10 (volume kitosan $10 \mathrm{~mL}$ dan serbuk gelatin $0,5 \mathrm{~g}$ ) sebesar 69,316 . Hal ini menunjukkan bahwa dengan penambahan serbuk gelatin pada larutan kitosan dapat meningkatkan kemampuan adsorben untuk menurunkan kadar logam $\mathrm{Pb}$ pada sampel yang digunakan hal ini terjadi karena interaksi kitosan dan gelatin yang memiliki gugus amina $\left(\mathrm{NH}_{2}\right)$ dengan ion logam terjadi karena proses pengkompleksan dimana penukaran ion, penyerapan dan pengkhelatan terjadi selama proses berlangsung. Ketiga proses tersebut tergantung dari ion logam masingmasing seperti penukaran ion logam Ca. Kitosan dan gelatin dengan sama-sama memiliki gugus aktif amina $\left(\mathrm{NH}_{2}\right)$ menunjukkan afinitas yang tinggi pada logam transisi golongan 3 , begitu pula pada logam yang bukan golongan alkali dengan konsentrasi rendah (Muzzarelli, 1973).

\section{KESIMPULAN}

Kitosan-gelatin dapat digunakan sebagai adsorben untuk menurunkan kadar logam $\mathrm{Pb}$. Penurunan kadar logam $\mathrm{Pb}$ yang optimum terdapat pada adsorben kitosan-gelatin (v/v) dengan perbandingan konsentrasi larutan kitosan 75 \% dan larutan gelatin $25 \%$ yakni sebesar 83,696 \% serta pada adsorben kitosan $2 \%$ ditambah serbuk gelatin $0,5 \mathrm{~g}$ yakni sebesar $69,316 \%$.

\section{Ucapan Terima Kasih}

Penulis mengucapkan terima kasih kepada civitas akademika STIPAP yang telah mendukung dalam penelitian ini, juga kepada Prof Basuki Wirjosentono, MS, Ph.D atas saran dan bimbingan yang baik sehingga penelitian ini dapat diselesaikan.

\section{DAFTAR PUSTAKA}

Amit, B., \& Minocha, A.K. (2006). Conventional and non conventional adsorbents for removal of pollutant from water- A review. Indian Journal of Chemical Technology, 13: 203-217.

Gómes-Estaca, J., López de Lacey, A., LópezCaballero, M.E., Gómez-Guillén, M.C., \& Montero, P. (2010). Biodegradable Gelatine-Chitosan Films Incorporated with Essential Oils as Antimicrobial Agents for Fish Preservation. Food Microbiology.

Endang, W., Laksono, J.I \& Prodjosantoso, A.K. (2006). The Adsorption Capasity of chitosan-alumina to $\mathrm{Cr}$ (III) and Ni(II) ion, Proceeding Paccon, Thailand, January 2006, 112.

Endang, W., Laksono, J.I., \& Prodjosantoso, A.K. (2008). Koadsorpsi Cr-Fe Oleh Kitosan. Saintek, 1:95-109.

Muzzarelli, R.A.A. (1973). Natural Chelating Polymer. New York. Pergamon Press.

Noviary, H. (2010). Studi Karakterisasi Pembuatan Kitin Dan Kitosan Dari Cangkang Belangkas (Tachypleusgigas) Untuk Penentuan Berat Molekul. Skripsi, Jurusan Kimia, FMIPA, USU.

Meriatna. (2008). Penggunaan Membran Kitosan untuk Menurunkan Kadar Logam Krom (Cr) dan Nikel (Ni) dalam Limbah Cair Industri Pelapisan Logam. Tesis, USU.

Syahriza, A. (2009). Kitosan Sumber Biomaterial Masa Depan, IPB Press. Bogor. 